\title{
Alfacalcidol as a modulator of growth of low grade non-Hodgkin's lymphomas
}

\author{
DAVID CUNNINGHAM， NIGEL L GILCHRIST， ROBERT A COWAN， GORDON J FORREST, \\ COLIN S MCARDLE, MICHAEL SOUKOP
}

\begin{abstract}
Ten patients with low grade non-Hodgkin's lymphoma (seven follicular small cleaved and three small lymphocytic) were treated with $1 \mu \mathrm{g}$ oral alfacalcidol ( $1 \alpha$-hydroxycholecalciferol) daily. Of the seven patients with lymphomas of follicular small cleaved subtype, one achieved complete and three partial remission, whereas none of three patients with small lymphocytic lymphomas responded. In seven of the 10 patients, $1,25(\mathrm{OH})_{2} \mathrm{D}_{3}$ receptors were measured in tissue from lymph nodes, and a positive correlation between the presence and amount of receptor and response to alfacalcidol was found.

These preliminary data suggest that alfacalcidol has appreciable antitumour activity in low grade non-Hodgkin's lymphomas.
\end{abstract}

\section{Introduction}

Low grade non-Hodgkin's lymphomas as defined in the working formulation of non-Hodgkin's lymphomas' consist of the following histological subtypes: small lymphocytic, follicular small cleaved cell, and follicular mixed small cleaved cell and large cell. They account for $30-45 \%$ of all lymphomas and are generally very responsive to single agent or combination chemotherapy. ${ }^{2}$ With the possible exception of the follicular mixed small cleaved cell and

Royal Infirmary, Glasgow G4 0SF

DAVID CUNNINGHAM, MB, MRCP, Cancer Research Campaign research fellow, department of medical oncology

NIGEL L GILCHRIST, FRACP, senior registrar, department of medical oncology

ROBERT A COWAN, BSC, PHD, lecturer, university department of pathological biochemistry

GORDON J FORREST, MB, senior house officer, department of medical oncology

COLIN S MCARDLE, MD, FRCS, consultant surgeon, university department of surgery

MICHAEL SOUKOP, MB, MRCP, consultant physician, department of medical oncology

Correspondence to: Dr Cunningham. large cell subtype,${ }^{3}$ however, the remission of disease obtained with such chemotherapy is not durable, and a pattern of continual relapse has been identified. ${ }^{+}$Thus although these tumours are compatible with long survival they can rarely be cured, and delaying the introduction of chemotherapy until it is clinically indicated is unlikely to compromise survival. ${ }^{5}$ During this treatment free period it is, therefore, reasonable to investigate therapeutic alternatives to chemotherapy.

The interrelation between vitamin D and the lymphomedullary system was recently reviewed ${ }^{6}$ after developments in research in this topic over the past five years. During this time 1,25-dihydroxyvitamin $\mathrm{D}_{3}\left(1,25(\mathrm{OH})_{2} \mathrm{D}_{3}\right)$ at near physiological doses has been shown to induce in vitro differentiation of murine and human leukaemia along monocyte and macrophage pathways. ${ }^{78}$ Moreover, this type of differentiation in a human leukaemia cell line is associated with the regulation of an oncogene's expression. ${ }^{9}$ An in vivo antitumour effect of alfacalcidol ( $1 \alpha$-hydroxycholecalciferol; $\left.1 \alpha-\mathrm{OHD}_{3}\right)$ has been shown by the suppression of the growth of sarcoma and Lewis lung tumours in mice, ${ }^{9 a}$ and mice inoculated with leukaemia cells survive longer when given $1,25(\mathrm{OH})_{2} \mathrm{D}_{3},{ }^{\text {, }}$, which also suggests in vivo antitumour activity. When this is coupled with the fact that malignant and activated $\mathrm{T}$ and $\mathrm{B}$ lymphocytes have $1,25(\mathrm{OH})_{2} \mathrm{D}_{3}$ receptors, which are not found on resting lymphocytes, ${ }^{10}$ then the potential of $1,25(\mathrm{OH})_{2} \mathrm{D}_{3}$ as an antitumour agent in human lymphoma and leukaemia becomes obvious.

The clinical course of low grade non-Hodgkin's lymphoma makes it the ideal type of tumour for investigating such a hypothesis, and the lack of toxicity of alfacalcidol makes a clinical study feasible. We report on the antitumour effect of alfacalcidol in 10 patients with low grade non-Hodgkin's lymphomas.

\section{Patients and methods}

Twelve patients (eight women, four men) with low grade non-Hodgkin's lymphomas entered the study. All had had stable disease for the preceding three months (except one who had had a recent recurrence). When possible each patient underwent lymph node biopsy on entry to the study; half of the specimen obtained was sent for routine histological examination and the remainder for measurement of $1,25(\mathrm{OH})_{2} \mathrm{D}_{3}$ receptor concentrations. The tissue reserved for measurement of receptor concentrations was immediately frozen in liquid nitrogen and stored at $-70^{\circ} \mathrm{C}$. Tissue was allowed to thaw on 
ice and a $10 \% \mathrm{wt} / \mathrm{vol}$ homogenate prepared using the buffer and homogenising conditions described by Rheinhardt et al. ${ }^{11}$ After centrifugation at $100000 \mathrm{~g}$ for 60 minutes the supernatant was incubated with increasing concentrations of tritiated and cold $1,25(\mathrm{OH})_{2} \mathrm{D}_{3}$ for 15 hours at $4^{\circ} \mathrm{C}$. Bound and free steroid was separated using dextran coated charcoal, ${ }^{12}$ and Scatchard curves were constructed after correction for non-specific binding. ${ }^{13}$ Protein concentration was measured by the method of Lowry et al. ${ }^{14}$

We measured serum concentrations of urea, electrolytes, calcium phosphate, magnesium, $1,25(\mathrm{OH})_{2} \mathrm{D}_{3}$, and parathyroid hormone; serum activities of alkaline phosphatase, aspartate transaminase, and alanine transaminase; full blood count; and erythrocyte sedimentation rate before starting treatment with alfacalcidol $1 \mu \mathrm{g}$ daily (One-Alpha, Leo Laboratories). These measurements were repeated each time the patient was reviewed (every three to four weeks). At each review response was assessed using the standard criteria of the World Health Organisation. ${ }^{15}$ These define complete remission as the absence of all clinically detectable malignant disease for at least four weeks; partial remission as a decrease of more than $50 \%$ in tumour size in at least $50 \%$ of the affected sites for at least four weeks; stable disease as no change in measurable disease for at least eight weeks; and progressive disease as an increase of more than $50 \%$ in measurable disease or the development of any new lesions. The clinician making the assessment did not know the receptor state of the patient. Treatment with alfacalcidol was continued until there was evidence of progression of the disease or toxicity.

\section{Results}

Routine histological examination showed that two patients had intermediate grade lymphomas ${ }^{1}$ and were thus unsuitable for treatment with alfacalcidol, but they were included in the table as information about their receptor state was available. The table shows the results of treatment with alfacalcidol. All patients except one (case 1) had normal biochemical values, including $1,25(\mathrm{OH})_{2} \mathrm{D}_{3}$ and parathyroid hormone concentrations, before and during treatment. In case 1 the patient had mild hypercalcaemia $(2.7 \mathrm{mmol} / 1 ; 10.8 \mathrm{mg} / 100 \mathrm{ml})$ for eight weeks after treatment with alfacalcidol was begun, which spontaneously returned to normal values. The treatment had no other toxic effects. Two patients (cases 9 and 10) had raised white cell counts before treatment $\left(61 \times 10^{9} / 1\right.$ and $\left.253 \times 10^{9} / 1\right)$ due to a mature lymphocytosis consistent with an exfoliating small lymphocytic lymphoma. As the lymphadenopathy in these patients increased during treatment with $1 \alpha-\mathrm{OHD}_{3}$ the white cell count rose further.

\section{Discussion}

In this study we showed that alfacalcidol had considerable antitumour activity in the treatment of low grade non-Hodgkin's lymphoma. This effect was restricted to the patients with lym- phoma of follicular small cleaved cell subtype, but this may reflect the small number of patients with the small lymphocytic subtype studied. Some correlation seemed to exist, however, between the presence and amount of $1,25(\mathrm{OH})_{2} \mathrm{D}_{3}$ receptor and subsequent response to alfacalcidol. This is important, as this receptor state may ultimately be used to determine a patient's suitability for treatment with alfacalcidol. The duration of treatment required to induce regression of the tumour ranged from three to 16 weeks. Therefore, in the absence of progressive disease or toxicity, we recommend that treatment should be continued for a minimum of six months. Increasing the dose of alfacalcidol to more than $1 \mu \mathrm{g}$ daily could add to toxicity, but we believe that it may be worth trying this in patients with low receptor concentrations who do not respond to $1 \mu \mathrm{g}$ daily and those who respond but then relapse.

The precise mechanism by which alfacalcidol produced regression of the tumours in our patients is not clear. Regression may have been mediated through a differentiation effect, analogous to that observed with the human leukaemia cell line, in which leukaemia cells were transformed into monocytes by culture with $1,25(\mathrm{OH})_{2} \mathrm{D}_{3}{ }^{8}$ It has also been shown, however, that $1,25(\mathrm{OH})_{2} \mathrm{D}_{3}$ inhibits the production of interleukin 2, a T lymphocyte growth factor, by activated human $T$ lymphocytes ${ }^{16}$ and that it can suppress the proliferation of and production of immunoglobulin by normal peripheral mononuclear cells. ${ }^{17}$ Thus it is possible, though speculative, that for lymphomas with $1,25(\mathrm{OH})_{2} \mathrm{D}_{3}$ receptors $1,25(\mathrm{OH})_{2} \mathrm{D}_{3}$ is an inhibitory growth regulator, mediated by suppression of production of interleukin 2.

Spontaneous regression of tumours is well documented in low grade non-Hodgkin's lymphoma, ${ }^{5}$ and it could be argued that the responses to alfacalcidol in this study were simply manifestations of this phenomenon. Spontaneous remission of the magnitude that occurred in our patients would, however, be extremely unusual; a previous review reported an incidence of $5 \%$, generally in untreated patients. ${ }^{18}$ Horning and Rosenberg described spontaneous remission in $23 \%$ of 83 patients with low grade lymphomas, and in a group with the follicular small cleaved cell subtype the figure was as high as $30 \%,{ }^{5}$ but the median time to regression was long (eight months) and the patients were highly selected: none had had chemotherapy, and they were included in the study only because at presentation they did not require treatment with chemotherapy.

In our patients there was some evidence that the regression of tumours was due to alfacalcidol, such as the presence of receptors in those who responded and the absence or low level of receptors in those who did not and a fairly good temporal relation between the introduction of alfacalcidol and response. It is interesting to speculate that the spontaneous regression described by Horning and

Response to alfacalcidol and $1,25(\mathrm{OH})_{2} D_{3}$ receptor concentrations

\begin{tabular}{|c|c|c|c|c|c|c|c|}
\hline $\begin{array}{l}\text { Case } \\
\text { No }\end{array}$ & $\begin{array}{l}\text { Sex, } \\
\text { age }\end{array}$ & $\begin{array}{l}\text { Histology, } \\
\text { date of diagnosis }\end{array}$ & $\begin{array}{l}\text { Previous } \\
\text { treatment }\end{array}$ & $\begin{array}{l}\text { Measurable } \\
\text { disease }\end{array}$ & Response & $\begin{array}{l}\text { Duration of response } \\
\text { (time taken to respond) }\end{array}$ & $\begin{array}{l}\text { Receptor level } \\
\quad(\mathrm{fmol} / \mathrm{mg})\end{array}$ \\
\hline 1 & $\mathrm{~F}, 55$ & FSC stage IVA, April 1982 & None & Lymphadenopathy, splenomegaly & Complete remission & 30 weeks ( 4 weeks) & Not done \\
\hline 2 & $\mathrm{~F}, 44$ & FSC stage IIIA, July 1978 & CHOP, radiotherapy & $\begin{array}{l}\text { Right axillary lymphadenopathy, } \\
\text { para-aortic nodes on computed }\end{array}$ & & & \\
\hline 3 & $F, 45$ & FCC & MYPp $C$ P & tomography & Partial remission & 38 weeks ( 16 weeks) & $2 \cdot 02$ \\
\hline 3 & $F, 45$ & FSC stage IVA, December 1973 & MVPP, CVP & $\begin{array}{l}\text { Splenomegaly, para-aortic nodes } \\
\text { on computed tomography }\end{array}$ & Partial remission & 29 weeks ( 3 weeks) & $1 \cdot 32$ \\
\hline 4 & $M, 61$ & FSC stage IIIA, December 1983 & Radiotherapy & Lymphadenopathy & Partial remission & 16 weeks ( 8 weeks) & $4 \cdot 07$ \\
\hline 5 & $F, 54$ & FSC stage IVB, October 1971 & MVPP, chlorambucil & $\begin{array}{l}\text { Lymphadenopathy, } \\
\text { hepatosplenomegaly }\end{array}$ & Progressive disease & & Not detected \\
\hline 6 & $M, 59$ & FSC stage IVB, May 1981 & MVPP, chlorambucil & $\begin{array}{l}\text { Lymphadenopathy, } \\
\text { hepatosplenomegaly }\end{array}$ & Progressive disease & & \\
\hline $\begin{array}{l}7 \\
8\end{array}$ & $\begin{array}{l}F, 47 \\
F, 55\end{array}$ & $\begin{array}{l}\text { FSC stage IVA, January } 1984 \\
\text { SL stage IVA, June } 1984\end{array}$ & $\begin{array}{l}\text { None } \\
\text { None }\end{array}$ & Pulmonary deposits & Progressive disease & & No tissue available \\
\hline & & & & splenomegaly & Stable disease & & $0 \cdot 8$ \\
\hline 9 & $M, 51$ & SL stage IVA, June 1976 & Chlorambucil & $\begin{array}{l}\text { Lymphadenopathy, } \\
\text { hepatosplenomegaly }\end{array}$ & Progressive disease & & Not done \\
\hline 10 & $M, 50$ & SL stage IVB, November 1978 & MVPP, chlorambucil & $\begin{array}{l}\text { Lymphadenopathy, } \\
\text { hepatosplenomegaly }\end{array}$ & Progressive disease & & 0.37 \\
\hline 11 & $\mathrm{~F}, 63$ & FSC stage IIIA, January 1983 & Ngne & Lymphadenopathy & $\begin{array}{l}\text { Not tested because } \\
\text { transformation to intermediate } \\
\text { grade lymphoma occurred }\end{array}$ & & $1 \cdot 53$ \\
\hline 12 & $F, 45$ & FSC stage IIIA, August 1977 & MVPP & Lymphadenopathy & $\begin{array}{l}\text { Not tested because } \\
\text { transformation to intermediate } \\
\text { grade lymphoma occurred }\end{array}$ & & $0 \cdot 28$ \\
\hline
\end{tabular}

FSC $=$ Follicular small cleaved cell subtype. $\mathrm{SL}=$ Small lymphocytic subtype. $\mathrm{CHOP}=\mathrm{Cyclophosphamide,} \mathrm{doxorubicin}$, vincristine, prednisone $. \mathrm{MVPP}=\mathrm{Mustine}$, vinblastine, procarbazine, prednisone. $\mathrm{CVP}=$ Cyclophosphamide, vincristine, prednisone. 
Rosenberg in patients with lymphomas in the United States may have been partly due to an effect of vitamin $D$, as the normal range for vitamin $\mathrm{D}$ is known to be higher in the United States than Great Britain and ingestion of multivitamin preparations is fairly common in the general population in the United States ${ }^{19}$ and may be more common among patients with cancer.

We cannot make any useful comment on the effect that alfacalcidol might have on the survival of patients from this study. Clearly this would require longer follow up and more patients in a randomised study. Nevertheless, if alfacalcidol could be substituted for cytotoxic treatment as a means of controlling disease without necessarily affecting survival this would represent a major advance in the treatment of low grade lymphomas: the replacement of a toxic treatment with a fairly non-toxic treatment is obviously beneficial, and more effective treatment of transformed low grade lymphomas might be achieved, as it has been suggested that these tumours respond so poorly to chemotherapy partly because they acquire resistant cell populations during exposure to chemotherapy in the low grade state.$^{20}$ Furthermore, the substitution of chemotherapy with alfacalcidol might reduce the risk of secondary leukaemia in patients with lymphoma because this risk is related to the duration of treatment with alkylating agents. ${ }^{21}$

These preliminary data suggest that the antitumour effect of alfacalcidol is not limited to in vitro systems or animal tumour models and that the drug may have an important role as a biological modifier in the management of non-Hodgkin's lymphomas.

We thank Leo Laboratories Limited for financial support; Miss Deborah Kinghorn, our secretary; and Mr Murray McKinnon for technical help.

\section{References}

1 Non-Hodgkin's Lymphoma Pathological Classification Project. National Cancer Institute sponsored study of classifications of non-Hodgkin's lymphomas: summary and description of a working formulation for clinical usage. Cancer 1982;49:2112-35.
2 Skarin AT, Canellos GP. Chemotherapy of advanced non-Hodgkin's lymphoma. In: Wolvey $W$, ed. Clinics in haematology. Philadelphia: W B Saunders, 1979:667-84

3 Anderson T, Bender RA, Fisher RI, et al. Combination chemotherapy in non-Hodgkin's lymphoma: results of long-term follow up. Cancer Treat Rep 1977;61:1057-66.

4 Schein PS, Chabner BA, Canellos GP, Young RC, DeVita VT. Non-Hodgkin's lymphoma: patterns of relapse from complete remission after combination chemotherapy. Cancer 1975;35: $354-7$.

5 Horning SJ, Rosenberg SA. The natural history of initially untreated low-grade non-Hodgkin's lymphomas. N Engl I Med 1984;311:1471-5.

6 Anonymous. Vitamin D and the lymphomedullary system [Editorial]. Lancet 1984;i:1105-6.

7 Abe E, Miyaura C, Sakagami H, et al. Differentiation of mouse myeloid leukaemia cells induced by 1a25-dihydroxyvitamin $D_{3}$. Proc Natl Acad Sci USA 1981;76:4990-4.

8 McCarthy DM, Miguel SFS, Freake HC, et al. 1,25-dihydroxyvitamin $\mathrm{D}_{3}$ inhibits proliferation of human promyelocytic leukaemia (HL60) cells and induces monocyte-macrophage differentiation in HL60 and normal human bone marrow cells. Leuk Res 1983;7:51-5.

9 Reitsma PH, Rothberg PG, Astrin SM, et al. Regulation of myc gene expression in HL-60 leukaemia cells by a vitamin D metabolite. Nature 1983;306:492-5.

9a Sato T, Takusagawa K, Asoo N, Konno K. Antitumour effect of 1-hydroxyvitamin $\mathrm{D}_{3}$. Tohoku f Exp Med 1982;138:445-6.

9b Honma $\mathrm{Y}$, Hozumi $M$, Abe $\mathrm{E}$, et al. 1 25-Dihydroxyvitamin $\mathrm{D}_{3}$ and 1 hydroxyvitamin $\mathrm{D}_{3}$ prolong survival time of mice inoculated with myeloid leukaemia cells. Proc Natl Acad Sci USA 1983;80:210-4.

10 ProvvediniDM, Tsoukas CD, Deftos LJ, Manolagas SC. 1,25-Dihydroxyvitamin D receptors in human leukocytes. Science 1983;221:1181-2.

11 Rheinhardt TA, Horst RL, Orf JW, Hollis BW. Microassay for 1,25-dihydroxyvitamin D not requiring high performance liquid chromatography: application to clinical studies. $f \mathrm{Clin}$ Endocrinol Metab 1984;58:91-8.

12 Preece MA, O'Riordan JLH, Lawson DEM, Kodicek E. A competitive protein binding assay for 25-hydroxycholecalciferol and 25-hydroxy ergocalciferol in serum. Clin Chim Acta 1974;54: 235-42.

13 Chamness GC, McGuire WL. Scatchard plots: common errors in correction and interpretation. Steroids 1975;26:538-42.

14 Lowry QH, Rosebrough NJ, Farr AL, Randall RJ. Protein measurement with the folin phenol reagent. F Biol Chem 1951;193:265-75.

15 Miller AB, Hoogstraten B, Stequet M, Winkler A. Reporting results of cancer treatment. Cancer 1981;47:207-14.

16 Tsoukas CD, Provvedini DM, Manolagas SC. 1,25-Dihydroxyvitamin $\mathrm{D}_{3}$ : a novel immunoregulatory hormone. Science 1984;224:1438-9.

17 Lemire JM, Adams JS, Sakai R, Jordan SC. 1,25 Dihydroxyvitamin $\mathrm{D}_{3}$ suppresses proliferation and immunoglobulin production by normal human peripheral blood mononuclear cells. $\mathcal{F}$ Clin and immunoglobulin prod

18 Wiernik PH. Spontaneous regression of hematologic cancers. Natl Cancer Inst Monogr 1976;44:35-8.

19 Smith PG, Jick H. Cancers among users of preparations containing vitamin A. Cancer 1978;42:808-11.

20 Armitage JO, Dick FR, Corder MP. Diffuse histiocytic lymphoma after histologic conversion: a poor prognostic variant. Cancer Treat Rep 1981;65:413-8.

21 Greene MH, Young RC, Merrill JM, DeVita VT. Evidence of a treatment dose response in acute nonlympocytic leukemias which occur after therapy of non-Hodgkin's lymphoma. Cancer Res 1983;43:1891-8.

(Accepted 19 August 1985)

\title{
Treatment with danazol and plasma glucagon concentration
}

\author{
GARETH WILLIAMS, FIONA LOFTS, HERMANN FUESSL, STEPHEN BLOOM
}

\begin{abstract}
The association between treatment with danazol and hyperglucagonaemia was studied. Plasma glucagon concentrations were measured during an oral glucose tolerance test in seven women taking danazol and six healthy controls not taking danazol. Results showed that treatment with danazol is associated with severe hyperglucagonaemia, and in three patients glucagon concentrations reached the range suggestive of glucagonoma.

It is important to recognise that this increasingly used drug may cause severe hyperglucagonaemia to prevent patients treated with danazol undergoing unnecessary investigations to localise glucagonoma.
\end{abstract}

Department of Medicine, Hammersmith Hospital, London W12 OHS

GARETH WILLIAMS, MA, MRCP, endocrinology registrar

FIONA LOFTS, MB, senior house officer

HERMANN FUESSL, MD, research fellow

STEPHEN BLOOM, DSC, FRCP, professor of endocrinology

Correspondence to: Professor S R Bloom, Francis Fraser Laboratories, Hammersmith Hospital.

\section{Introduction}

Grossly increased plasma glucagon concentrations $(>50 \mathrm{pmol} / 1$ $(>17 \cdot 4 \mathrm{ng} / \mathrm{ml})$ ) were found fortuitously in a woman receiving danazol for premenstrual exacerbations of lupus erythematosus. Known causes of hyperglucagonaemia were excluded. Glucagon concentrations were found to parallel the dosage of danazol, suggesting that hyperglucagonaemia was due to the drug. To explore this possibility we measured plasma glucagon concentrations during an oral glucose tolerance test in seven women taking danazol and six healthy controls.

\section{Patients, methods, and results}

Seven women aged 20-45 (mean 33.9) years treated with danazol (100-600 $\mathrm{mg} /$ day for four to 24 weeks) for endometriosis (five patients) or mastalgia (two patients) were randomly selected from the gynaecological outpatient clinic. One patient was taking phenobarbitone and lorazepam for epilepsy and another norethisterone $20 \mathrm{mg} /$ day. Body weight ranged from 45.5 to $82.7 \mathrm{~kg}$ (mean $62.7 \mathrm{~kg}$ ). The six control women did not differ noticeably from the group treated with danazol in either age (range 23-40, mean 29.8 years) or body weight (range 50 to $68 \mathrm{~kg}$, mean $58.3 \mathrm{~kg}$ ); one was taking an oral contraceptive. 